\title{
THE OUTCOMES OF ROUND OFF ARTISTIC GYMNASTICS LEARNING SKILL
}

\author{
Dini Rosdiani*, Firmansyah dlis**, Mulyana*** \\ STKIP Pasundan Cimahi \\ State university of jakarta \\ State university of jakarta \\ dinirosdiani11@gmail.com \\ firmansyahdlis@unj.ac.id \\ mulyana@unj.ac.id
}

\begin{abstract}
Abstrack
The purpose of this study was to determine differences in learning outcomes artistic gymnastics round off the overall use of teaching methods and teaching methods section to motor ability in STKIP Pasundan Cimahi. The method used is an experimental method to the design by level of $2 \times 2$. The population is all students STKIP Pasundan Cimahi level II Prodi. PJKR Academic Year 2015/2016 by the number of 360 people and the sample of 40 people with the sampling technique used purposive sampling. The research instrument used achievement test round off the artistic gymnastics. This research was conducted as many as 12 meetings. The results showed that: (1) There are differences in learning outcomes between the artistic gymnastics round off the overall teaching methods and teaching methods section. (2) There is no interaction between teaching methods and learning outcomes of motor abilities to round off the artistic gymnastics in STKIP Pasundan Cimahi. (3) There are differences in learning outcomes between the artistic gymnastics round off the overall teaching methods and teaching methods to the student section that has a motor of high ability. (4) There is no difference in learning outcomes between the artistic gymnastics round off the overall teaching methods and teaching methods to the student section that has a motor ability is low...
\end{abstract}

Keywords: Teaching Methods, Motor Ability, Round Off

\section{A. Characteristics of Artistic Gymnastics}

Artistic gymnastics skills on floor numbers are generally characterized by tumbling and acrobatic movements. Tumbling implies fast and explosive, whose motion is a series of motion, while acrobatics are characterized by a movement that utilizes a lot of elaborate, unique motion skills and requires an element of balance. 
Floor gymnastics skills are fundamental to skills in other tools. Readhead (2005: 617): that the basic exercises that must be possessed by the athlete in this sport include, front and rear roll, wheels, handstand, round off, handspring, etc. "Basic Skills: Floorwork Forward rolls, backward rolls, cartwheels, handstands, round off and arab spring, handspring, back flip, flic flac, headspring, backward somersault, forward somersault" Motion technique performed is the work of some or together Of several muscles, in an anatomical study, it is explained that, "Coordination among muscle movements often are the result of several skeletal muscles acting as a group. Most skeletal muscles are arranged in opposing (antagonistic) pairs at joints that are, flexors extensors, abductors adductors, and so on ". Tortora, Derrickson, (2012: 369): The point is that motion / skill is the result of muscle coordination working together, in the form of synergistic (anticular) and antagonistic (opposite) movements, such as the work of the flexor muscle and Extensor, abductor and adductor, and so on. The joints and muscles that are dominant in this round off technique include joints in the upper limb member (upper limb), lower limb members (limbs) and joints and muscles around the body (trunk). The joints and muscles are like the following picture.
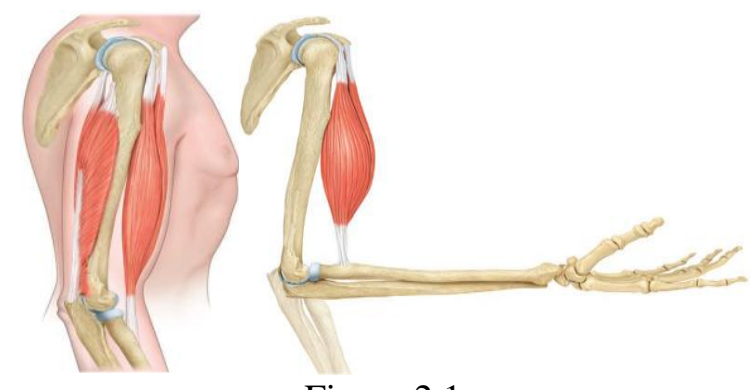

Figure 2.1

Side view Joints and muscles on Upper limb (Source: Gerard J. Tortora, Bryan Derrickson, p.367)

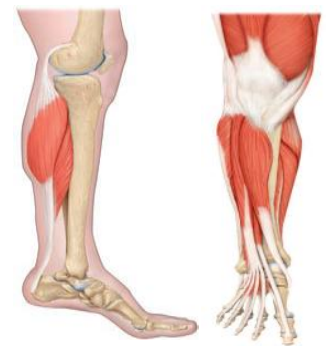

Figure 2.2

Side view Joints and muscles in Lower limb (Source: Gerard J. Tortora, Bryan Derrickson, p.444-435) 


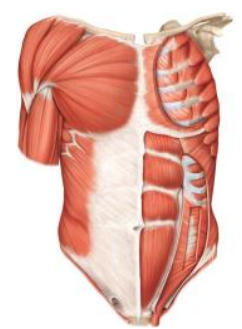

(Source: Gerard J. Tortora, Bryan Derrickson, p.402)

The muscles and bones play a major role in the round off movement in artistic gymnastics.

B. Artistic Gymnastics Round Off Technique

Initial attitude

Standing erect, both legs tight, arms at the sides. The muscles used are leg muscles, upper limbs and lower limbs, one of which is the thigh muscle (rectus femoris), the muscle of the shin (anterior tibialis), and the calf muscle (gastrocnemius).

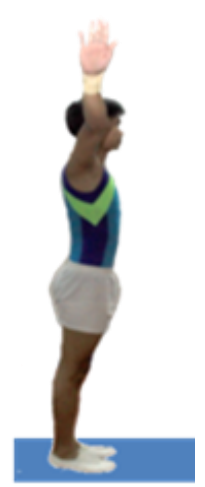

Early Attitude Round Off

Source: Documentation Pengda Persani Jabar

Implementation Attitude

1. The left leg is lifted straight ahead, and both arms straight up. Muscles that function are both leg muscles, abdominal muscles (rectus abdominis), and both arm muscles, including the upper arm muscles biceps and triceps. 


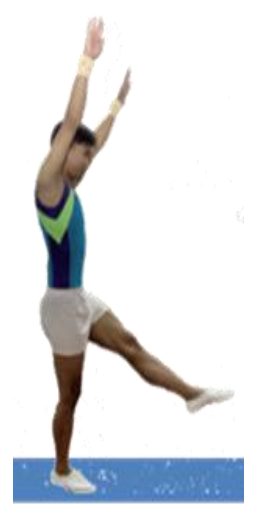

Figure 2.2

Round Off Attitude

Source: Documentation Pengda Persani Jabar

2. Drop the left foot into the mat and the body to the left side, put the left palm to the matreline aligned in front with the left foot. The right leg is raised to the top of the body, and the right arm is still above the body.

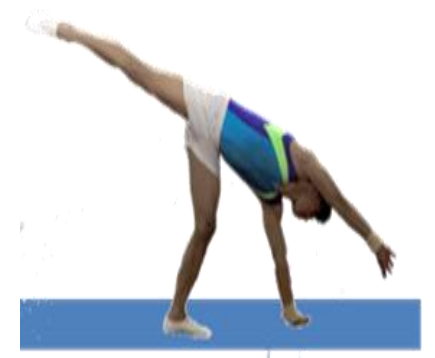

Figure 2.3

Round Off Attitude

Source: Documentation Pengda Persani Jabar

3. Swing your right leg up and over with your right palm to the mat. Keep the left foot on the mat, so that both feet lift straight up. The muscles used are the muscles of the shoulders, hands, arms, abdominal muscles and leg muscles.

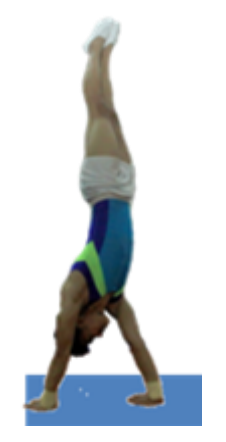


Figure 2.4

Round Off Attitude

Source: Documentation Pengda Persani Jabar

4. Drop both legs simultaneously onto the mat. Both arms straight up. The muscles used are the muscles of the shoulders, hands, arms, abdominal muscles and leg muscles

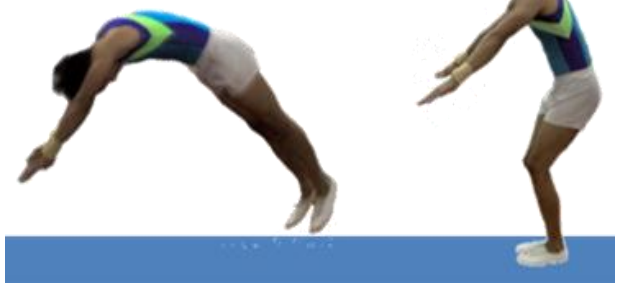

Figure 2.5

Round Off Attitude

Source: Documentation Pengda Persani Jabar

5.The final attitude Stand up straight, both arms in the body saping, and the view pointed to the original place. Coordination of all the muscles of the body, especially the most dominant is the leg muscles.

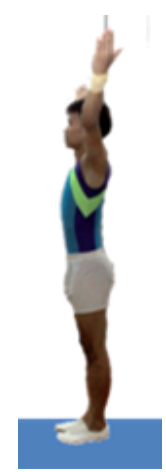

Figure 2.5

Round Off End Attitude

Source: Documentation Pengda Persani Jabar

The conclusion of learning result of artistic gymnastics round off is: A movement unit consisting of:

A. Perform hand stand by rotating on erect axis.

B. Rejects with both hands on when both feet will land on the floor.

Thus the learning result of artistic gymnastics round off in this research is the ability obtained by the students through the process of giving the material by the lecturer with the steps / stages of the round off movement of artistic 
gymnastics. These steps refer to the artistic gymnastics round off rubric consisting of 3 (five) assessment elements, namely: (1) Initial attitude ( $\max$ score $=16$, $\min =$ 4), (2) attitude of implementation ( $\max$ score $=48$, Min = 12), (3) Final attitude $(\max$ score $=16, \min =4)$. Thus the maximum score for each student is 80 and the minimum score is 20 .

\section{B. Learn}

In learning there is a unity of activities that can not be separated between students who study with lecturers who teach so that interaction that mutually support. In learning, lecturers are not only tasked to deliver some information but as a driver in teaching and learning process. Usman, (2010: 4).Arsyad, (2010: 1): if the learning process is formally organized in schools, none of this is intended to direct changes to students in a planned way, both in the aspects of knowledge, skills, and attitudes. The interactions that occur during the learning process are influenced by the environment, among others by students, lecturers, librarians, principals, materials or lessons (books, modules, leaflets, magazines, video or audio recordings, and the like), and various Learning resources and facilities (overhead projector, audio and video tape recorder, radio, television, computer, library, laboratory, learning resource center etc.) Winkel, (2008: 17) learning is a change from not being able to the already Capable and this process occurs over a period of time. While Ali, (2003: 8) suggests teaching is all deliberate efforts in order to provide possibilities for students to the learning process in accordance with the objectives that have been formulated. Roestiyah, (2008: 29) suggests that the components of teaching and learning process include: 1) learning objectives, 2) learning materials, 3) teaching methods, 4) learning resources, 5) media for learning, 6) interaction management teaching and learning, 7) Evaluation, 8) Students, 9) Lecturers, and 10) Development in teaching and learning process.

\section{Teach}

Teaching is training, giving lessons (Full Dictionary of Bahasa Indonesia). Teaching in principle is to guide students in teaching activities which implies that teaching is an effort to organize the environment in relation to students and teaching materials, resulting in the process of teaching and learning. : Nasution, (2002: 27), who formulates that teaching is an activity to organize or regulate the environment as well as possible and connect with children, so that there is a process of teaching and learning. The conclusion of teaching methods is a knowledge of the ways of teaching used by a teacher or instructor, teaching methods used to convey information differently in the way adopted to establish students in mastering the skills knowledge and attitude of each teacher need to know and understand about the level of maturity and level Willingness to learn a student. Thus, he will easily determine what method of teaching he will use.

Agus Mahendra, (273-275): states that the global method or whole or 
whole method is a way of teaching that goes from the general to the particular. The teaching method of the section is a method of teaching by using some parts, such as parts by section and then connected again with other parts / material which of course is related to the problem. In this case, the same task is designed using different difficulty levels. Students determine the lowest level of their task and continue at the next level (Entwistle, Noel Routledge, 2013.).

\section{Motor ability}

Motor ability is very important in sports activities because it is needed to support body movement, in order to perform the movement well. A skilled movement can be done well if the motor ability is adequate. Nurhasan suggests the ability of general motor ability theoretically will certainly provide a general ability, which includes various aspects of the factors contained in various physical types. Therefore this test is a battery test consisting of several test items.

More specifically about the notion of motor ability is the capacity of a person to be able to perform a variety of movements that require courage in sports. Nurhasan, Hasanudin (2007: 127). Growth support to lifelong development is meaningful. It is therefore necessary to study motor development during childhood. Saputra, Yudha. (2008: 12). Johnson and Nelson (1969) quoted Nurhasan and Cholil as saying that this motor ability test consists of several types of test items that measure the aspects of speed, power, agility, eye and hand coordination, balance. In addition there are sometimes test items that measure the power and endurance aspects.

\section{Explosive Power and Muscle Durability}

Strength (strength) associated with muscle contraction. Thus, clearly the power will underlie all motor appearances. But there is one thing that we believe in, the muscle strength applied in appearance, is not a single skill. Now, the ability to contract muscles has been differentiated on the basis of the energy source used to contract. Contractions in a short time and with intensity (characteristic of muscle activity at a fast run) occur in the absence of oxygen, which is called aerobic endurance contraction. Every special skill always requires more than one energy system, a rather prominent system, and designs an exercise appropriate to the energy system. Syahrastani. (2012: 67).

Flexibility, Corbin and Noble define flexibility as "a range of joint motions that exist in one or a group of joints." It seems that not only contributes to the skill, but also prevents injury. (Syahrastani FIK UNP. 2012) p. 68. Balance, Many studies of balance have proven that there are at least two types of balance, static balance and dynamic balance. The balance is the ability to maintain the balance of the body in a stationary position, while the dynamic balance is the ability to maintain the balance of the body in a moving position. A dynamic balance is required by the sport that requires a change of motion, all of a sudden.Coordination 
is an elusive motor skill. In fact.

\section{METHODOLOGY}

The purpose of this research in general is to know the difference of learning result of artistic gymnastics round off using whole teaching method and method of teaching part with motor ability in STKIP Pasundan Cimahi. The research method used is experimental method with research design using by level $2 \times 2$.

Table 3.1. Research Design Based By Level

\begin{tabular}{|c|c|c|}
\hline \multirow{2}{*}{ Motor Ability (B) } & \multicolumn{2}{|c|}{ Teaching Method (A) (A) } \\
\cline { 2 - 3 } & Whole (A1) & section (A2) \\
\hline High(B1) & A1B1 & A2B1 \\
\hline Low(B2) & A1B2 & A2B2 \\
\hline
\end{tabular}

Information :

A1 = group of students taught by the whole teaching method.

A2 = group of students taught by the teaching methods section.

A1B1 = group of students who are taught by the whole teaching method and have high ability motor ability.

A1B2 = group of students who were taught by the whole teaching method and have low ability motor ability

A2B1 = group of students taught by the method of teaching part and having high ability motor ability.

$\mathrm{A} 2 \mathrm{~B} 2$ = group of students who are taught by the teaching method part and have low ability motor ability

\section{RESEARCH RESULT}

1. There is a difference in learning outcomes Artistic Gymnastics Round Off between the whole teaching method and the section. To examine the differences between the whole teaching method and the teaching methods section, used ANAVA. ANAVA test results using SPSS are presented as follows.

Paired Samples Test

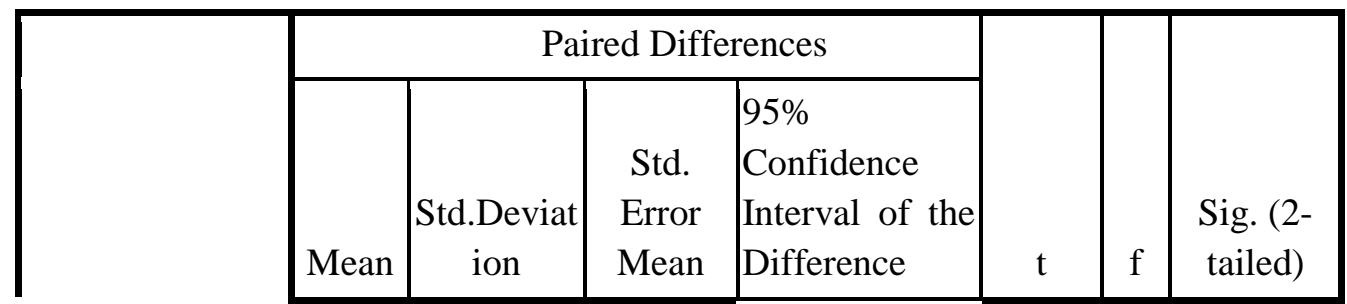




\begin{tabular}{|r|c|c|c|c|c|c|c|c|}
\cline { 3 - 9 } & & & & Lower & Upper & & & \\
\hline air 1 $\begin{array}{r}\text { roundoff } \\
\text { - metode }\end{array}$ & 57.625 & 9.529 & 1.507 & 54.577 & 60.673 & 38.246 & 9 & .000 \\
\hline
\end{tabular}

The calculation results show that the significance value is 0.000 , which is smaller than 0.05 . This indicates a significant difference between the whole teaching method group and the section teaching method. That is, the whole teaching method has unique characteristics that are different from the method of teaching the part to the learning outcome of artistic artistic round off. In this case, the group with the whole teaching method has a learning outcome of artistic gymnastics round off which tends to be higher than the group of teaching methods section.

2. There is an interaction between teaching methods and motor skills against the learning outcomes round off artistic gymnastics. To see the interaction between the teaching method and the motor ability against the learning outcomes round off artistic gymnastics used univariate analysis of variance. The results of this interaction analysis test are presented as follows.

Tests of Between-Subjects Effects

\begin{tabular}{|l|c|c|c|c|c|}
\hline \multicolumn{1}{c|}{ Source } & $\begin{array}{c}\text { Type } \\
\text { III Sum of } \\
\text { Squares }\end{array}$ & df & $\begin{array}{c}\text { Mean } \\
\text { Square }\end{array}$ & F & Sig \\
\hline Corrected Model & $664.275^{\mathrm{a}}$ & 3 & 221.425 & 2.779 & .055 \\
\hline Intercept & 139830.625 & 1 & 139830.625 & 1755.135 & .000 \\
\hline $\begin{array}{c}\text { metode } \\
\text { motorability }\end{array}$ & 664.275 & 3 & 221.425 & 2.779 & .005 \\
\hline Error & 2868.100 & 36 & 79.669 & & \\
\hline Total & 143363.000 & 40 & & & \\
\hline Corrected Total & 3532.375 & 39 & & & \\
\hline
\end{tabular}

Dependent Variable:roundoff

a. $\mathrm{R}$ Squared $=.188$ (Adjusted R Squared $=.120$ )

Ho: There is no interaction between teaching methods and motor abilityAgainst the overall round off learning outcomes

Hi: There is an interaction between teaching methods and motor ability againstOverall round off learning outcomes

Decision-making :

- If probability $>0.05$, then Ho is accepted

- If probability $<0.05$, then Ho is rejected

Based on the calculation of Paired Samples Test analysis on the table on the interaction between teaching methods and motor ability to roundless learning 
outcomes as a whole it is known that the value of the results of the Paired Samples Test test on the data above shows the significance value of $0.005<0.05$ means Ho rejected. So the conclusion is that there is interaction between teaching method and motor ability to round off learning result as a whole.

To clarify the interaction lines between teaching methods and motor ability to the overall round off learning outcomes will be presented through the interaction lines presented in Figure 4.5 as follows:

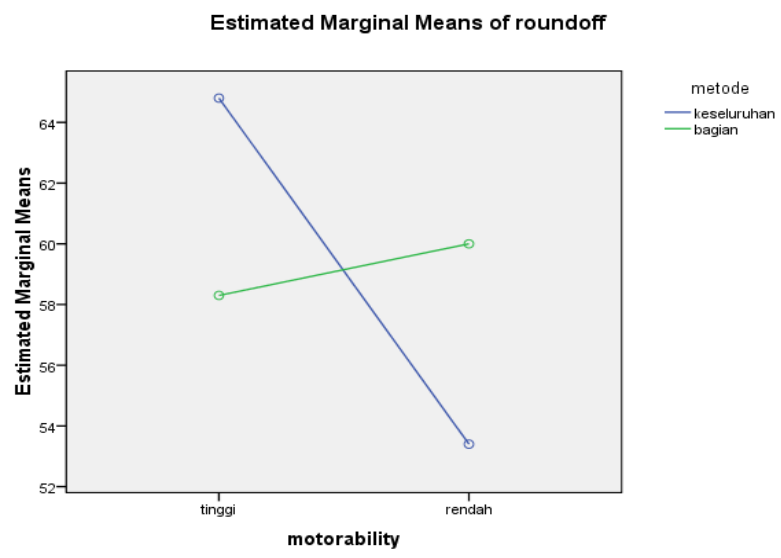

Picture. The line of interaction between teaching methods and motor ability to the overall round off learning outcomes

3. There is a difference in learning outcomes of artistic gymnastics round-off between the whole teaching method and the teaching method of the section towards students who have high ability motorTo test the difference between the whole teaching method and the teaching method of the section that has high ability motor is used ANAVA. ANAVA test results using SPSS presented as follows:

\section{Paired Samples Test}

\begin{tabular}{|c|c|c|c|c|c|c|c|c|}
\hline & \multicolumn{5}{|c|}{ Paired Differences } & \multirow[b]{3}{*}{$\mathrm{t}$} & \multirow[b]{3}{*}{$\mathrm{f}$} & \multirow[b]{3}{*}{$\begin{array}{l}\text { Sig. (2- } \\
\text { tailed) }\end{array}$} \\
\hline & \multirow[b]{2}{*}{ Mean } & \multirow[b]{2}{*}{$\begin{array}{c}\text { Std. } \\
\text { Deviation }\end{array}$} & \multirow[b]{2}{*}{$\begin{array}{c}\text { Std. Error } \\
\text { Mean }\end{array}$} & \multicolumn{2}{|c|}{$\begin{array}{l}95 \% \\
\text { Confidence } \\
\text { Interval of the } \\
\text { Difference }\end{array}$} & & & \\
\hline & & & & Lower & Upper & & & \\
\hline $\begin{array}{cc}\text { Pair } & \text { roundoff } \\
1 & \text { - metode }\end{array}$ & 57.625 & 9.529 & 1.507 & 54.577 & 60.673 & 38.246 & 9 & .000 \\
\hline
\end{tabular}


Paired Samples Test

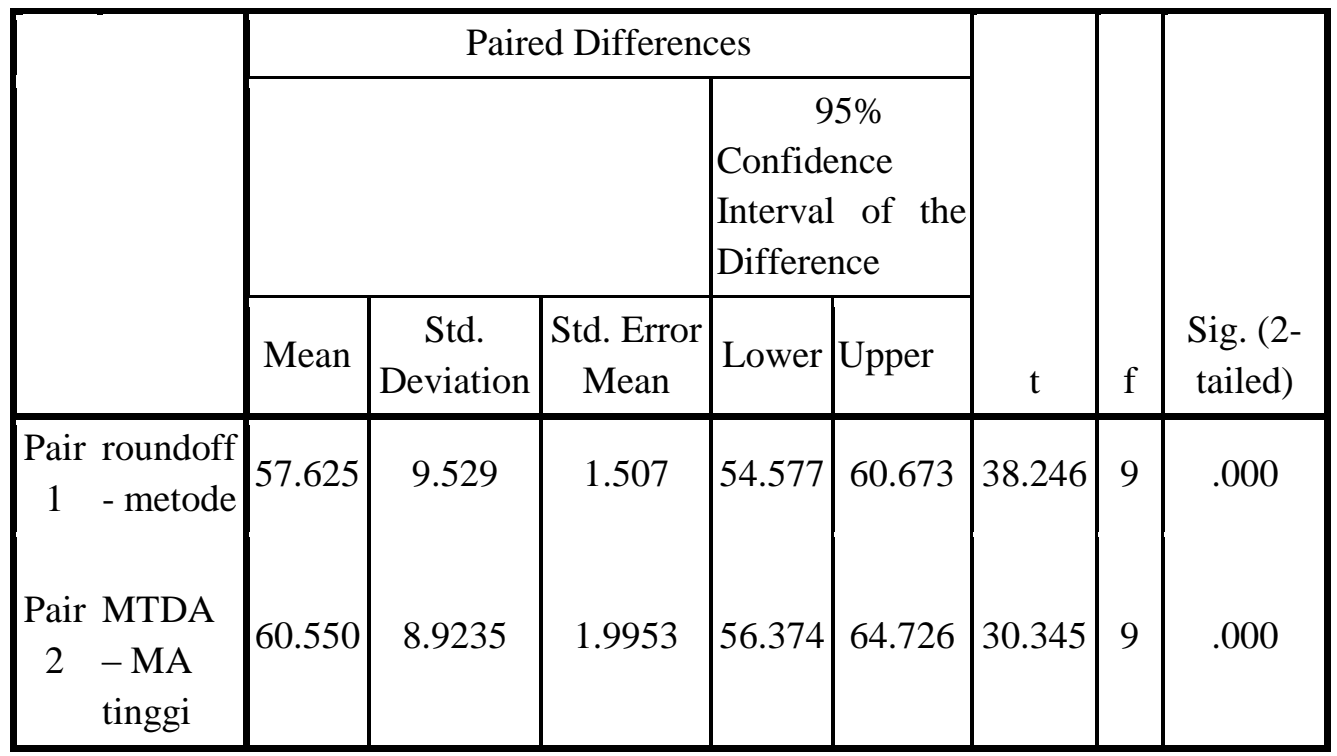

Ho: There is no difference in learning outcomes round off between teaching methods Overall and teaching methods section on high motor ability.

Hi: There is a difference in learning outcomes round off between teaching methods Overall and teaching methods section on high motor ability.

Decision-making :

- If probability $>0.05$, then Ho is accepted

- If probability $<0.05$, then Ho is rejected

Based on the calculation of Paired Samples Test analysis results in Table 4:10 on the difference of learning outcomes round off between the whole teaching method and teaching methods section on high motor ability note that the value of test results Paired Samples Test on the data shows a significance value of 0.000 $<0.05$ means Ho is rejected. So the conclusion is that there is a difference in learning outcomes round off between the whole teaching method and the teaching method of the section on high motor ability.

4. There is a difference in learning outcomes of artistic artistic round-offs between the whole teaching method and the teaching methods of the section on students with low motor ability. Based on the results of calculations performed, the results can be as follows:

Paired Samples Test

\begin{tabular}{|l|l|l|l|l|l|l|l|}
\hline & \multicolumn{1}{|l|}{} & $\begin{array}{c}\text { Std. } \\
\text { Deviation }\end{array}$ & $\begin{array}{c}\text { Std. Error } \\
\text { Mean }\end{array}$ & $\begin{array}{l}95 \% \text { Confidence } \\
\text { Interval of the } \\
\text { Difference }\end{array}$ & t & Df & $\begin{array}{c}\text { Sig. (2- } \\
\text { tailed) }\end{array}$ \\
\hline
\end{tabular}




\begin{tabular}{|c|c|c|c|c|c|c|c|c|c|}
\hline & & & & & Lower & Upper & & & \\
\hline $\begin{array}{l}\text { Pair } \\
1\end{array}$ & $\begin{array}{l}\text { MTBD } \\
\text {-MA } \\
\text { Lower }\end{array}$ & 54.7000 & 9.69047 & 2.16686 & 50.16472 & 59.23528 & 25.244 & 19 & .000 \\
\hline
\end{tabular}

Criteria for acceptance and rejection of the hypothesis:

Ho: There is no difference in learning outcomes round off between teaching method Overall teaching and teaching methods section on low motor ability.

Hi: There is a difference in learning outcomes round off between teaching methods

Overall teaching and teaching methods section on low motor ability.

Decision-making :

- If probability $>0.05$, then Ho is accepted

- If probability $<0.05$, then Ho is rejected

Based on calculation result of Paired Samples Test analysis test in table 4:10 about difference of learning result of round off between teaching method overall and method of teaching part at motor ability low known that value of test result of Paired Samples Test at the data show significance value equal to 0,000 $<0,05$ meaning Ho is rejected. So the conclusion is that there is a difference in learning outcomes round off between the whole teaching method and the teaching method of the section on the low motor ability.

All teaching methods both the whole teaching method and the teaching methods of the section are equally proven to be effective in improving the learning outcome of artistic artistic round offs. However, from the findings of this study the implication is that the whole teaching method can be used effectively for students with high motor ability. Whereas for students who have low motor ability will be better in learning result of artistic gymnastics round off if given method of teaching part.

For Lecturers / Teacher Penjas, In order to pay attention to the use of teaching methods tailored to the level of ability of students in this ability motor ability students. In teaching motion or game skills, the whole or whole lesson form should be done first and then broken into pieces. The method will be more easily adapted by students in studying a motion skill compared with the method of teaching the part. For Practitioners Gymnastics Branch, To pay more attention to motor ability owned by students before conducting training. Not only that, in seeking the seeds of athletes in school, trainers should be able to consider the motor abilities that are owned by students to be able to excel in sports, especially artistic gymnastics.

\section{CONCLUSION}

First, there is a difference in learning outcomes round off artistic 
gymnastics between the whole teaching method and the teaching methods section. Secondly, there is an interaction between teaching method and motor ability to the learning outcome of artistic gymnastics round off at STKIP Pasundan Cimahi. Thirdly, there is a difference of learning outcome of artistic gymnastics round off between the whole teaching method and the teaching method of the part towards the student who has high ability motor. Fourthly, there is a difference in learning outcomes of artistic gymnastics round-off between the whole teaching method and the teaching method of the section on students with low motor ability.

\section{REFRENCES}

Agus Mahendra, (2007), The Teaching Module for Teaching Motoric Teaching. Bandung: FPOK UPI Bandung

Ali, M, (2003), Education Research Strategy. Bandung: Space

Arifin, (2014), Effective Learning Style. Bandung: Alfabeta

Azhar Arsyad, (2010), Learning Media. Jakarta: PT Raja Grafindo Persada

Bruner, Jerome S, (2006), The Process of Education. New York: Vintage Books

Drowatzky, John N. (1981). Motor Learning: Principles And Practices, 2nd. Ed. Minneapolis, Minnesota:Burgess Publissing Comapany ,.

Gerard J. Tortora, Bryan Derrickson, (2012), Principles Of Anatomy \& Physiology, 13th Edition. USA:

John Wiley \& SonsLutan, Rusli, (2005) Learning Motor Skills Introduction to Theory and Methods. Revised Edition.Jakarta: Directorate General of Higher Education Depdikbud

Lloyd Readhead, (2005): Mens Gymnastics Coaching Manual. England: Springfield Boo

M. Uzer Usman, (2010), Becomes a Professional Teacher. Bandung: PT Remaja Rosdakarya

Nasution, S, (2002), Various Approaches in Teaching and Learning Process. Jakarta: Bina Aksara

Nurhasan, Cholil Hasanudin., (2007). Bandung: UPI FPOK, Sports Test and Measurement

Oxendine, Joseph B, (1968), Psychology of Motor learning New York: Appleton

Rahantoknam, B. Edward, (1987) Learning Motorics: Theory and Its Application

in Physical Education. Jakarta: Educational Development of Educational Institutions.

Roestiyah, (2008), Teaching and Learning Strategy. Jakarta: Rieneka Cipta

Saputra, M. Yudha. (2008), Bandung.FPOK UPI. Development and Learning Motorik.Winkel, (2008), Psychology Teaching. Jakarta: Gramedia Pustaka Tama.

Singer, Robert N, (1980), Motor Learning and Human Performance. New York: Macmillan Publishing

Syahrastani, (2012) (UNJ Jakarta Influence Learning Media and Motor Ability on Learning Results Technique of Student Chest Pool FIK UNP

Ted A. Braumgartner, Andrew S. Jackson and Matthew T. Mahar, (2007) Measurement for Evaluation in Physical Education and Exercise Science. Mc. Graw-Hill

Winkel, (2008), Teaching Psychology. Jakarta: Gramedia Pustaka Tama 